\title{
ANALISIS PANDANGAN GOLONGAN YANG MENYOKONG DAN MENENTANG PENGGUNAAN TALFĪ DALAM PERUNDANGAN ISLAM
}

\section{An Analysis on the Views of the Supporters and Opponents in the Usage of Talfiq in Islamic Law}

\author{
Mohd Hafiz Jamaludin ${ }^{1}$ \\ Ahmad Hidayat Buang ${ }^{2}$
}

\begin{abstract}
In the modern world, there are an abundance of problems and issues that have not been discussed by previous Muslim scholars in the field of religious rituals ('ibādāt), commerce (mu 'àmalāt), family relations (munākaḥāt), crimes (jināyāt), etc. In addressing this current development, contemporary Muslim scholars have adopted various methods for solving these particular problems and issues. Among those methods employed include combining the views of previous scholars of the various madhhabs, commonly referred to as talfiq. Indeed, the issue of talfiq still invites debate
\end{abstract}

\footnotetext{
Ph.D Candidate, Department of Shariah and Law, Academy of Islamic Studies, University of Malaya, 50603 Kuala Lumpur, hafiz_usul@um.edu.my

2 Head of Department and Professor at Department of Shariah and Law, Academy of Islamic Studies, University of Malaya, 50603 Kuala Lumpur, ahidayat@um.edu. my
} 
among those who support and oppose this concept. This study has analysed the views of the various scholars on these issues by looking in depth at the arguments by who agree and disagree on the usage of talfiq. The finding of this study indicates that the explanations used by both sides were strong in supporting their views although there is still rooms for criticism. Therefore the researcher has choosen a neutral and cautious (ihtiyāt) stance by stating that the usage of talfiq is permissible only at the final stage whereby the solution in a particular madhhab is not able to provide the best possible solutions in overcoming the difficulties faced by the community.

Keywords: talfiq, madhhab, Islamic law, principles of Islamic jurisprudence

\section{PENDAHULUAN}

Perkembangan yang pantas dalam kehidupan moden dewasa ini telah mengakibatkan timbul berbagai-bagai permasalahan sama ada dalam permasalahan ibadat, ekonomi, kemasyarakatan dan lain-lain. Sungguhpun begitu, para fuqaha pada era ini telah berusaha untuk menyelesaikan semua permasalahan ini dengan memberikan hukum-hukum fiqh yang bertepatan dengan hikmah syarak dan tuntutan semasa. Bagi memenuhi tuntutan pengeluaran hukum yang relevan dengan realiti kehidupan pada masa kini, kebanyakan hukum dikeluarkan melalui perbincangan sekumpulan para ulama, atau lebih dikenali sebagai ijtihād jam $\bar{a} \mathfrak{c}$, yang dianggotai institusi-institusi atau badan-badan yang berautoriti untuk mengeluarkan fatwa. Pengeluaran hukum atau fatwa seperti ini mampu menghasilkan hukum yang lebih tepat dan teliti hasil perbincangan para ulama dan pakar yang mempunyai kemahiran tinggi.

Selain itu, kebanyakan fatwa yang dikeluarkan pada ketika ini juga merupakan gabungan pendapat para ulama terdahulu sehingga menghasilkan satu hukum baru yang tidak pernah dihasilkan oleh para ulama silam. Inilah yang digelarkan sebagai konsep talfiq oleh para ulama usul fiqh. Para ulama telah berselisih pendapat tentang hukum penggunaan konsep talfiq sehingga mengundang kritikan terhadap pengeluaran hukum atau fatwa berdasarkan konsep ini. Justeru itu, dalam artikel ini, penyelidik akan membahaskan secara terperinci tentang konsep talfiq, perbincangan para ulama berkenaan dengannya dan pendapat yang dipilih berpandukan kepada perbahasanperbahasan dan hujah-hujah para ulama berkenaan konsep talfíq ini. 


\section{TALFĪQ DARI SUDUT BAHASA}

Perkataan talfiq yang merupakan kata terbitan daripada kata kerja laffaqa (لَّقَ), mempunyai beberapa pengertian dari sudut bahasa iaitu menghimpunkan, bersesuaian dan pendustaan yang ditokok tambah. Antara penggunaan makna-makna ini dalam perkataan orang arab ialah (كَنََّتْ الثَّْْبَ) yang bererti "menghimpunkan satu bahagian kain dengan bahagian yang lain kemudian menjahitnya", (تَالَفََ الْقَوْمُ) yang bererti "kaum ini telah bersepakat dalam

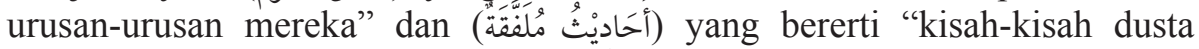
yang ditokok tambah sehingga kelihátan indah". ${ }^{3}$ Berdasarkan pengertianpengertian di atas, terdapat hubungan yang rapat di antara maksud talfiq dari sudut bahasa dan istilah melalui beberapa ciri-ciri penting bagi konsep talfiq iaitu penggabungan hukum, kesesuaian atau keperluan kepada penggabungan tersebut dan penghasilkan hukum yang nampak pada zahir lebih indah dan mudah untuk diamalkan.

\section{TALFĪQ DARI SUDUT ISTILAH}

Para ulama juga telah menakrifkan talfíq dengan takrif yang pelbagai. Walau bagaimanapun, penyelidik cenderung untuk memilih takrif yang dikemukakan oleh al-Hiilwānī (m.1890M) di dalam kitabnya berjudul al-Wasm fì al-Wasym. Beliau telah menakrifkan talfiq sebagai "mencampurkan dua pendapat mazhab dalam satu permasalahan sehingga menghasilkan satu gabungan hukum yang tidak diiktiraf oleh kedua-duanya, sama ada percampuran itu dilakukan pada asal permasalahan atau pada permasalahan lain yang merupakan kesan daripada asal permasalahan tersebut." " Takrif ini dipilih kerana menurut penyelidik ia merupakan satu takrif yang lengkap bagi menjelaskan maksud sebenar bagi konsep talfiq seperti mana yang perincian yang akan dijelaskan di bawah. ${ }^{5}$

3 Ibn Manẓūr, Muhammad bin Mukram, Lisān al- 'Arab, vol. 10 (Beirūt: Dār alȘadr, t.t.), 330 \& 331; al-Fayruz al-Abadi, Muhammad bin Ya'qūb, al-Qamūs alMuhiț, vol. 2 (Beirūt: Dār Iḥyā’ al-Turāth al-'Arab̄̄, 2000), 1222.

4 al-Ḥilwān̄i, al-Wasm fì al-Wasym (Qāhirah: Matba'ah al-Maymaniyyah, 1905), 55.

5 Penyelidik memilih takrif ini setelah membandingkan dengan tiga lagi takrif iaitu takrif yang dikemukakan oleh al-Banī (m.1933), al-Malibari (m.1579) dan alRuwayti`. Pemilihan penyelidik terhadap takrif al-Hilwānī berbanding tiga takrif yang lain adalah disebabkan takrif ini tidak terlalu ringkas dan tidak terlalu panjang dalam menjelaskan maksud talfìq. Dalam masa yang sama, takrif al-Ḥilwānī ini juga masih mampu untuk menghimpunkan semua ciri-ciri dan bahagian-bahagian yang terdapat dalam konsep talfiq serta mengeluarkan perkara-perkara lain yang 
Takrif ini menjelaskan bahawa talfiq adalah amalan percampuran pendapat di antara dua mazhab yang berbeza. Percampuran tersebut hendaklah berlaku dalam satu permasalahan sahaja. Percampuran itu juga akan menyebabkan terhasilnya satu hukum yang tidak diiktiraf oleh mana-mana mazhab. ${ }^{6}$ Takrif ini turut menjelaskan bahagian-bahagian yang terdapat di dalam konsep talfiq iaitu talfiq dalam asal permasalahan dan talfíq dalam kesan daripada asal permasalahan. Talfiq dalam asal permasalahan bermaksud talfiq yang berlaku dalam satu permasalahan seperti dalam permasalahan wuduk sahaja. ${ }^{7}$ Talfiq dalam kesan daripada asal permasalahan bermaksud talfíq berlaku dalam dua permasalahan, tetapi permasalahan yang kedua merupakan kesan daripada permasalahan yang pertama. Contohnya, permasalahan solat merupakan kesan daripada permasalahan wuduk kerana wuduk merupakan salah satu syarat sah bagi solat. ${ }^{8}$ Begitu juga permasalahan talak yang merupakan kesan daripada permasalahan nikah, kerana hukum talak hanya sah setelah berlaku akad nikah yang sah. ${ }^{9}$ Hubungan di antara permasalahan pertama dan kedua ini telah menyebabkan percampuran pendapat di antara kedua-duanya masih boleh menyebabkan berlakunya amalan talfiq. Ini kerana, hubungan di antara kedua-dua permasalahan menyebabkan kedua-duanya dianggap seolah-olah sebagai satu permasalahan yang sama seperti mana yang disyaratkan dalam amalan talfiq.

Takrif al-Hiilwānī juga telah mengeluarkan konsep taqlid kerana taqlid tidak disyaratkan berlaku percampuran mazhab. Sekiranya seseorang mengikut pandangan satu mazhab tertentu, maka dia boleh dihukumkan sebagai seorang muqallid. Begitu juga, sekiranya dia mengikut pandangan beberapa mazhab, maka dia juga dianggap sebagai bertaqlid kepada pandangan mazhabmazhab tersebut serta dalam masa yang sama telah mengamalkan talfiq. Ini menunjukkan bahawa taqlid adalah lebih umum daripada talfiq. Seseorang itu

tidak boleh dikategorikan sebagai talfìq. Sila rujuk al-Banī, 'Umdah al-Tahqīq fi al-Taqlid wa al-Talfíq (Damshiq: Dār al-Qadirī, 1997), 183; Abū Bakr Muhammad Shata al-Dumyatī al-Bakrī, I'ānah al-Ṭālibìn, vol. 4 (Qāhirah: Dār Iḥyā' al-Kutub al-'Arabiyyah, t.t.), 218; al-Ruwayti', al-Tamadhhub, vol. 2 (Riyāḍ: Dār alTadmuriyyah, 2013), 1039.

6 Ibn al-'Uqayl, Abū al-Wafa' 'Alī bin 'Uqayl, al-Waḍh fì Ușūl al-Fiqh, vol. 5 (Beirūt: Mu’assasah al-Risālah, 1999), 237.

7 al-Safarinī, al-Tahqūq fì Buṭlān al-Talfìq (Riyāạ: Dār al-Sumay’i, 1998), 159; alḤilwānī, al-Wasm fì al-Wasym, 56.

8 Ayah 'Abd al-Salām, 'al-Talfīq wa Tatabbu' al-Rukhas wa Taṭbīqātuhu fĩ al'Ibādāt wa al-Aḥwāl al-Shakhsiyyah', (Master in Islamic Judiciary, College of Graduate Studies, Hebron University, Hebron, Palestin, 2006), 140.

9 al-Ḥilwānī, al-Wasm fì al-Wasym, 57. 
boleh dikatakan sebagai bertaqlid kepada pandangan mazhab tertentu dan tidak mengamalkan talfiq. Dia juga boleh dikatakan sebagai bertaqlid dan bertalfiq kepada pandangan beberapa mazhab yang berbeza sehingga menghasilkan satu hukum yang tidak diiktiraf oleh mana-mana mazhab. Selain itu, dia juga boleh dikatakan sebagai bertaqlid kepada pandangan beberapa mazhab yang berbeza, tetapi tidak menyebabkan terhasil satu hukum yang tidak diiktiraf oleh mana-mana mazhab. Pada ketika, dia masih dianggap sebagai muqallid dan tidak melakukan amalan talfiq. ${ }^{10}$

Seterusnya, takrif al-Hilwān̄̄ turut dapat mengeluarkan konsep tatabbu 'alrukhas. Ini kerana konsep tatabbu' al-rukhas tidak mensyaratkan berlakunya amalan percampuran mazhab. Seseorang boleh dianggap sebagai melakukan tatabbu' al-rukhas apabila mencari-cari pendapat-pendapat yang mudah dan $s y \bar{a} z$ dari sesebuah mazhab sahaja. ${ }^{11}$ Konsep talfiq pula tidak disyaratkan bertujuan untuk mencari pendapat yang lebih mudah. Terkadang seseorang itu melakukan amalan talfiq dengan tujuan untuk mencari pandangan yang lebih kuat dalilnya sehingga menghasilkan satu hukum yang lebih berat daripada pandangan mazhabnya sendiri. ${ }^{12}$ Oleh itu, tatabbu' al-rukhas lebih umum dari satu sudut kerana ia tidak mensyaratkan berlakunya amalan percampuran mazhab. Akan tetapi, dari sudut lain, talfiq lebih umum kerana talfiq tidak semestinya berlaku dengan tujuan mencari pandangan yang lebih mudah daripada setiap mazhab. Justeru itu, hubungan di antara talfiq dan tatabbu *

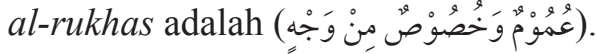

\section{HUKUM PENGGUNAAN KONSEP TALFĪQ}

Perbahasan yang menjadi tumpuan dalam artikel ini ialah berkenaan hukum penggunaan konsep talfiq dalam perundangan Islam. Perbahasan ini merupakan perbahasan yang penting disebabkan konsep talfiq sentiasa menjadi perdebatan para ulama berkenaan keharusan penggunaannya dalam penyelesaian hukum syarak. Sekalipun para ulama yang membincangkan permasalahan talfiq telah membentangkan dalil-dalil yang digunakan bagi menyokong pendapat mereka, akan tetapi perbincangan secara tuntas terhadap setiap dalil yang telah dikemukakan sebelum ini masih mempunyai ruang untuk kajian lanjutan yang

10 Hassan Ahmad (Datuk Seri, Ahli Majlis Penasihat Syariah Bank Negara Malaysia; Mantan Mufti Kerajaan Negeri Pulau Pinang 1997-2014), dalam temu bual beliau dengan penyelidik, pada 18 Ogos 2015.

11 al-Zarkashī, al-Baḥr al-Muḥiț, vol. 6 (Hurghada: Dār al-Șafwah, 1992), 325.

12 Taqī al-Dīn 'Alī bin 'Abd al-Kafī al-Subkī, Fatawā al-Subkī, vol. 1 (Beirūt: Dār al-Kutub al-'Ilmiyyah, 2004), 152. 
lebih terperinci dilakukan terhadap dalil-dalil tersebut. Daripada penelitian yang dilakukan oleh penyelidik, masih terdapat ruang bagi dalil-dalil yang dikemukakan sebelum ini untuk dikritik dan diperbincangkan agar dalil-dalil yang digunakan dapat dipastikan kekuatan atau kelemahan yang terdapat padanya. Selain itu, penyelidik juga mendapati bahawa terdapat dalil-dalil yang digunakan tidak bertepatan dengan konsep talfiq seperti mana takrif yang dipilih oleh penyelidik di atas. Sehubungan dengan itu, ia menghasilkan satu dalil yang tidak tepat kerana ia tidak merujuk kepada konsep talfiq yang sebenar seperti mana yang dikehendaki dan diperbincangkan oleh para ulama usul fiqh sebelum ini.

\section{Perselisihan Pendapat Berkenaan Hukum Talfíq}

Penyelidik akan membahagikan perselisihan pendapat berkenaan hukum talfiq ini kepada golongan yang mengharamkan penggunaan talfiq dan golongan yang mengharuskan penggunaan talfiq. Penyelidik akan menyatakan dalildalil yang dipegang oleh kedua-dua belah pihak berserta perbincangan terhadap dalil tersebut. Seterusnya, penyelidik akan memilih pendapat yang mempunyai dalil yang lebih kuat dan bebas daripada kritikan sebagai pendapat yang räjih dan wajar menjadi pegangan umat Islam pada masa kini ketika membuat sebarang penyelesaian bagi hukum syarak.

\section{Golongan yang Mengharamkan Penggunaan Talfĩq berserta Dalil yang Digunakan}

Pendapat yang mengharamkan penggunaan talfiq banyak diriwayatkan daripada ulama-ulama muta'akhkhirin sama ada daripada kalangan ulama mazhab Hanafì, Malikī, Shāfi'ī dan Hanbalī. al-Ḥilwān̄̄ menyebut di dalam kitabnya al-Wasm fi al-Wasym bahawa pendapat yang mengharamkan talfiq merupakan pendapat yang muktamad daripada mazhab Shāfi' $\overline{1}$, Hanafī dan Hanbalī. ${ }^{13}$ Muhammad al-Dussuqi pula mengatakan bahawa pendapat yang mengharamkan talfíq merupakan pandangan yang merujuk kepada tarīqah al-miṣriyyīn daripada kalangan Malikiyyah. ${ }^{14}$ Antara ulama-ulama yang

al-Hiilwānī, al-Wasm fì al-Wasym, 55.

14 al-Dussuqi, Shams al-Dīn Muḥammad 'Arafah, Hāshiyah al-Dussuqi 'ala alSharh al-Kabīr (Qāhirah: Dār Iḥyā' al-Kutub al-'Arabiyyah, t.t.), 1:20. Antara tokoh-tokoh daripada tariquh al-mișriyyin daripada kalangan Malikiyyah adalah seperti Ibn al-Qasim al-'Itqi (m.806M), Ibn Wahab al-Qurashi (m.812M), Asyhab bin 'Abd al-'Aziz (m.819M) dan Ibn 'Abd al-Hakam (m.829M). Sila rujuk 'Alī Jum'ah, al-Madkhal iIa Dirāsah al-Madhāhib al-Fiqhiyyah (Qāhirah: Dār alSalām, 2009), 142. 
mengharamkan talfìq ialah Ibn Daqīq al-'Id (m.1302M), Taqī al-Dīn alSubkī (m.1355M), al-Isnawī (m.1370M), al-Rafi'̄i (m.1226M), ${ }^{15}$ al-Zarkashī (m.1392M), ${ }^{16}$ Ibn Hajar al-Haythamī (m.1567M), al-Qarafī (m.1285M), al-Shațib̄̄ (m.1388M), ${ }^{17}$ 'Ala' al-Dīn al-Haskafī (m.1677M), al-Safarin̄̄ (m.1774M) dan Ibn 'Abidīn (m.1836M). ${ }^{18}$ Antara ulama mu'āsirīn yang mengharamkan talfiq ialah 'Alawi al-Saqqaf, Muḥammad bin 'Uthmān alHakim dan Badran Abū al-'Inin. ${ }^{19}$ al-Ghazzalī (m.1111M) juga cenderung kepada pendapat yang mengharamkan talfiq sekalipun tidak menggunakan istilah talfiq itu sendiri. Beliau menyebut di dalam kitabnya al-Mustaşa " "tidak harus bagi orang awam untuk memilih pendapat daripada beberapa mazhab yang sesuai bagi dirinya pada setiap masalah". ${ }^{20}$

Golongan yang mengharamkan talfiq ini berpegang dengan beberapa dalil bagi menyokong pendapat mereka. Dalil pertama yang ingin dijelaskan di sini ialah mereka berpandangan bahawa Syariat Islam tidak perlu kepada penggunaan konsep talfiq. Ini disebabkan amalan talfiq merupakan satu tindakan mempermain-mainkan agama. Golongan yang mengamalkan talfiq disamakan dengan golongan Ibahiyyin iaitu mereka yang suka mengharuskan dan menghalalkan perkara-perkara yang diharamkan dalam Islam. Amalan talfiq juga dianggap sebagai terkeluar daripada amalan para ulama mujtahid disebabkan gabungan pendapat daripada dua imam mazhab ini tidak diiktiraf oleh kedua-dua mazhab dan juga mana-mana imam mazhab yang lain. Justeru itu, talfiq dihukumkan sebagai haram oleh para ulama muhaqqiqinn. ${ }^{21}$

Dalil ini dikritik dengan mengatakan bahawa gabungan pendapat dua mazhab ini pada hakikatnya lahir daripada satu pendapat sahaja kerana ia

15 Zayn al-Dīn bin 'Abd al-'Aziz Al-Malibari, Fath al-Mu in, vol. 4 (Beirūt: Dār alFikr, 2002), 251.

16 al-Zarkashī, al-Baḥr al-Muhiț, vol. 6, 323.

17 al-Shāțib̄i, al-Muwāfaqāt, vol. 5 (al-Khubar: Dār Ibn al-‘Affan, 1997), 103

18 al-Ruwayti', al-Tamadhhub, vol. 2, 1069 \& 1070.

19 al-Saqqaf, 'Alawi Muhammad, al-Fawa'id al-Makkiyyah (Beirūt: Dār al-Kutub al-'Ilmiyyah, 2008), 85; 'Abd al-'Aziz Ahmad al-'Usfur, Fatawā 'Ulama' al'Ahsa'wa Masa'iluhum, vol. 1 (Beirūt: Dār al-Basha'ir al-Islāmiyyah, 2001), 376; Badran, Abū al-'Inin, Ușūl al-Fiqh (Iskandariah: Mu'assasah Shabab al-Jami'ah., t.t.), 490.

20 al-Ghazali, Abū Ḥamid Muḥammad bin Muḥammad, al-Mustașfā, vol. 4 (Madinah: al-Jami'ah al-Islāmiyyah-Kuliyyah al-Sharī'ah, t.t.), 154.

21 al-Safarin̄̄, al-Tahqūq fì Buṭlān al-Talfìq, 171; al-Ḥilwān̄i, al-Wasm fì al-Wasym, 56; Maszlee Malik, Talfiq: Beramal dengan Pelbagai Mazhab (Shah Alam: Karya Bestari Sdn. Bhd., 2005), 57. 
lahir daripada satu sumber dan Syariat yang sama. Penggabungan ini juga lebih bersesuaian dengan keluasan yang diberikan oleh Syariat Islam ini di mana Allah SWT tidak menjadikan kesusahan di dalam agamaNya. Kritikan ini dijawab semula dengan menolak dakwaan yang mengatakan gabungan pendapat daripada dua mazhab, sehingga menyebabkan berlaku amalan talfiq, pada hakikatnya adalah satu pendapat sahaja. Kenyataan ini bertentangan dengan hakikat dalam permasalahan fiqh yang membenarkan perselisihan pendapat para ulama dalam permasalahan ijtihädiyyah. Ini sekaligus menunjukkan bahawa pendapat para ulama dalam mazhab adalah banyak dan berbilang-bilang sekalipun pendapat-pendapat ini dikeluarkan daripada sumber dan Syariat yang sama. Bahkan perselisihan ini dianggap sebagai satu rahmat seperti mana yang disabdakan oleh Baginda Nabi SAW اختلاف) yoleru itu, dakwaan bahawa semua pendapat dalam mazhab pada hakikatnya adalah satu pendapat sahaja adalah tertolak. ${ }^{23}$

Dalil kedua yang dipegang oleh golongan ini ialah talfíq dianggap sebagai haram kerana ia boleh membawa kepada banyak kerosakan dan akibat yang berbahaya. Pintu ini sekiranya dibuka akan merosakkan Syariat disebabkan kurangnya sifat warak, sikap berhati-berhati dan mengambil berat tentang urusan agama dalam kalangan manusia pada waktu ini. Ditambah pula dengan keinginan manusia terhadap tuntutan hawa nafsu semakin hari semakin bertambah. Manakala individu yang mendakwa dirinya mempunyai ilmu pula, sangat mudah untuk mengeluarkan fatwa. Justeru itu, sekiranya pintu talfíq ini dibuka, ia akan menyukarkan lagi proses penyelesaian terhadap masalahmasalah yang sedang berlaku dan juga menghilangkan kehebatan mazhab dalam kalangan umat Islam. ${ }^{24}$

Antara contoh kerosakan yang dikemukakan oleh golongan yang mengharamkan talfiq ialah talfiq boleh membawa kepada menghalalkan zina dan arak. ${ }^{25}$ Sebagai contoh, seorang lelaki yang mengeluarkan mahar

22 'Ala' al-Dīn 'Alī bin Husam al-Dīn al-Burhān Furī, Kanz al- 'Ummal, vol. 10 (Beirūt: Mu'assasah al-Risālah, 1985), 136.

23 al-Ḥilwān̄i, al-Wasm fì al-Wasym, 56.

24 al-Shāțib̄i, al-Muwāfaqāt, vol. 5, 101; Fareeha Khan, 'Traditionalist Approaches to Shariah Reform: Mawlana Ashraf Ali Thanawi Fatwa on Women Right to Divorce', (PhD, The University of Michigan, United States of America, 2008), 64.

25 'Udaybat, 'al-Tarakhkhus fī Masa'il al-Ikhtilaf fī al-Fiqh al-Islāmī: Dirāsah Ta'siliyyah Tatbiqiyyah-Masa'il Mu'āmalāt fì Qararat Majmā' al-Fiqh al-Islāmī fī Jaddah Anmudhajan', (PhD, The World Islamic Sciences and Education University, Amman, Jordan, 2012), 75: al-Mayman, Nasir 'Abd Allāh , 'al-Talfìq fì al-Ijtihād wa al-Taqlid', dalam al-Nawāzil al-Tasyri' 'iyyah (Al-Dammam: Dār Ibn al-Jawzī, 2008), 15; al-Ruwayti', al-Tamadhhub, vol. 2, 1079; Maszlee Malik, Talfìq: Beramal dengan Pelbagai Mazhab. 55-57. 
untuk berkahwin dengan seorang perempuan yang baligh, berakal dan tidak mempunyai suami dan 'iddah. Lalu, perempuan ini menerima lamaran lelaki tersebut dengan bertaqlid mazhab Hanafī yang tidak mensyaratkan wali, dan bertaqlid dengan mazhab Malikī yang tidak mensyaratkan saksi. Ini merupakan hakikat sebenar amalan zina yang diharamkan syarak dan ia berpunca daripada amalan talfìq di antara mazhab Hanafī dan Malikī. ${ }^{26}$ Bagi contoh arak pula, golongan ini berhujahkan kepada satu syair yang disampaikan oleh Abū Nuwwas tentang pendapat Imam Abū Hanīfah yang menghalalkan tuak dan pendapat Imam al-Shāfi'‘̄ yang mengatakan bahawa arak dan tuak adalah benda yang sama. Kemudian, Abū Nuwwas telah mencampurkan kedua-dua pendapat tadi dengan mengatakan sekiranya tuak harus diminum di sisi Imam Abū Hanīfah, maka arak juga harus diminum kerana kedua-duanya adalah sama di sisi Imam Shāfi ‘̄i. ${ }^{27}$

Pengkritik terhadap dalil ini menolak bahawa amalan talfiq boleh membawa kepada zina seperti contoh di atas. Ini disebabkan, sekiranya permasalahan di atas dihukumkan sebagai zina, maka para ulama pasti akan menyatakan secara jelas tentang pengharamannya. Selain itu, para ulama juga akan menjelaskan bahawa perempuan tersebut tidak layak untuk mendapat mahar sekiranya berlaku persetubuhan, anak yang lahir tidak dinasabkan kepada bapanya dan mereka tidak boleh saling mewarisi. Sebaliknya, tidak berlaku penjelasan seperti di atas kerana ia hanya dianggap sebagai syubhah akad. Akad ini tetap dihukumkan sebagai haram di mana lelaki dan perempuan tersebut akan dikenakan hukum ta'zìr. Akad ini juga dianggap haram disebabkan mereka berdua cuba mencari pendapat yang mudah daripada setiap mazhab. ${ }^{28}$ Walau bagaimanapun, kritikan ini boleh dijawab semula dengan mengatakan sekalipun permasalahan di atas tidak dianggap sebagai zina menurut pandangan pengkritik, ia masih lagi dihukumkan sebagai perkara haram sehingga mengakibatkan pelakunya boleh dikenakan hukum ta'zīr. Justeru itu, ia masih tidak menafikan hujah golongan penentang bahawa talfiq tetap membawa kepada perkara yang haram.

Berkenaan dengan hujah syair Abū Nuwwas yang menghalalkan arak, pengkritik dalil ini mengatakan ia tidak boleh dijadikan hujah kerana Abù

\footnotetext{
26 al-Safarinī, al-Tahquīq fì Buțlān al-Talfìq, $171 \& 172$.

27 al-Safarin̄̄, al-Tạ̣qīq fì Buțlān al-Talfìq, 174 \& 175; al-Hifnawī, Tabsir alNujaba' bi- Haqūqāt al-Ijtihād wa al-Taqlid wa al-Talfìq wa al-Ifta' (Qāhirah: Dār al-Hadīth, 1995), 266 \& 267.

28 al-'Atibi, 'al-Talfìq bayn al-Madhāhib al-Fiqhiyyah wa 'Alaqātuhu bi Taysīr alFatwa', (Seminar Garis Panduan Fatwa anjuran al-Majmā' al-Fiqh al-Islami di Mekah, Arab Saudi, pada 17-20 Januarin 2009), 29.
} 
Nuwwas bukan seorang ulama sehingga perkataannya boleh dijadikan sebagi hujah. Mereka juga berpendapat, pengharaman arak merupakan hukum yang telah disepakati oleh para ulama dan tidak terdapat seorang pun yang menghalalkannya dengan menggunakan apa jua kaedah sekalipun. ${ }^{29}$ Kritikan ini juga boleh dijawab semula oleh golongan yang mengharamkan talfiq dengan mengatakan sekiranya mereka membenarkan talfiq dilakukan dalam masalah lain, maka talfiq juga perlu dibenarkan dalam masalah ini juga

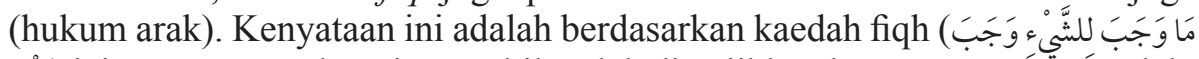
(لمثْله iaitu sesuatu perkara itu, apabila telah diwajibkan ke atas sesuatu masalah, máka wajib juga ia digunakan dalam masalah yang seumpama dengannya. ${ }^{30}$ Ia dikuatkan lagi dengan kaedah yang disebut oleh al-Safarinī di dalam risalahnya:

$$
\text { مردود أنّ كلّ ما أدّى إلى حظظور فهو مظور، و كلّ قول يلزم منه إباحة محرّم فهو }
$$

"Setiap perkara yang membawa kepada perkara yang haram, maka ia juga adalah haram, dan setiap pendapat yang membawa kepada mengharuskan perkara yang haram, maka pendapat itu ditolak..." 31

Oleh itu, sekiranya konsep talfíq boleh membawa kepada mengharuskan zina dan arak yang telah disepakati pengharamannya di sisi para ulama, maka konsep talfiq juga hendaklah dihukumkan sebagai haram berdasarkan kepada kaedah di atas.

Bahaya daripada amalan talfiq ini juga boleh dilihat daripada kemunculan individu-individu yang dikenali sebagai 'mufti siber' yang membenarkan kepada orang awam untuk memilih, mengambil dan menggabungkan manamana fatwa yang diberikan sehingga menghasilkan amalan talfiq. Fatwafatwa yang diberikan meliputi aspek perkahwinan dan perhubungan sebelum berkahwin. Terdapat juga laman web yang menyerupai perkhidmatan mencari pasangan tetapi memberi khidmat nasihat perkahwinan dalam Islam. ${ }^{32}$ Bahayabahaya daripada amalan talfiq seperti inilah yang mendorong para ulama untuk menghadkan pengeluaran fatwa kepada mereka yang berkelayakan sahaja. Ini merujuk kembali kepada kebanyakan ayat al-Quran yang mengandungi makna yang samar-samar (mujmal dan mutashābih). Penafsiran ayat al-Quran juga

\footnotetext{
29 Maszlee Malik, Talfiq: Beramal dengan Pelbagai Mazhab, 87.

30 al-Shāțibī, al-Muwāafaqāt, vol. 5, 101.

31 al-Safarinī, al-Tahqūq fì Buțlān al-Talfìq, 172.

32 Zaman, 'Amrikan Shari'a: The Reconstruction of Islamic Family Law in the United States', South Asia Research, 28/2 (2008): 191.
} 
perlu dikaitkan dengan sebab penurunan sesuatu ayat dan hadis-hadis daripada Rasulullah SAW. Jika tidak, sesuatu penafsiran ayat al-Quran tersebut boleh menyebabkan berlaku banyak penyelewengan dan terkadang boleh membawa kepada kekufuran. ${ }^{33}$

Dalil seterusnya iaitu dalil ketiga bagi golongan yang mengharamkan talfiq ialah ijm $\bar{a}$ " para ulama. Mereka mengatakan bahawa hukum yang terhasil daripada talfiq merupakan hukum yang tidak diiktiraf oleh manamana mujtahid. Oleh itu, hukum yang terhasil daripada talfiq merupakan hukum yang batil dengan ijma $\bar{a}^{\prime}$ ulama. ${ }^{34}$ Dalil ini telah mendapat kritikan hebat daripada golongan yang mengharuskan talfiq kerana dakwaan $i j m \bar{a}$ ' ini tidak dapat diterima disebabkan masih terdapat ramai ulama yang berselisih pendapat berkenaan dengannya. ${ }^{35}$ Ini dikuatkan lagi dengan kebanyakan para ulama tidak menyatakan secara jelas naqal (sumber) bagi ijmā' tersebut. Justeru itu, dalil ijma ' ini adalah tertolak kerana ijma ' tidak memadai dengan sekadar sangkaan dan kemungkinan semata-mata. ${ }^{36}$

Para pendokong pengharaman talfiq agak berlembut ketika menjawab kritikan ini dengan mengakui bahawa sememangnya tidak terdapat ijma ' yang jelas berkenaan pengharaman talfiq. Cuma mereka mengatakan dakwaan $i j m \bar{a}$ ' yang disebut oleh kebanyakan ulama muta'akhkhirin itu adalah disebabkan pendapat yang bertentangan dengannya adalah pendapat yang sangat lemah. Oleh itu, maksud ijmá ' di sini ialah persepakatan sebahagian besar para ulama mazhab tanpa menafikan bahawa masih terdapat pendapat-pendapat terpencil dalam setiap mazhab yang mengharuskan amalan talfiq. Ibn Hajar turut menyatakan amalan talfiq ini sebagai bertentangan dengan ijm $\bar{a}$ ' ulama, seolah-olah beliau menganggap pendapat lain yang bertentangan dengannya itu sebagai tidak wujud disebabkan kelemahan dan kenadirannya. ${ }^{37}$ Al-Ruwayti pula berpandangan maksud ijm $\bar{a}$ ' di sini ialah $i j m \bar{a}$ ' kedua-dua orang mujtahid bahawa amalan talfiq di antara kedua-dua mazhab ini akan menghasilkan

33 Gesink, 'Islamic Reformation: A History of Madrasa Reform and Legal Change in Egypt', Comparative Education Review, 50/3 (2006): 340.

34 Fareeha Khan, 'Traditionalist Approaches to Shariah Reform: Mawlana Ashraf Ali Thanawi Fatwa on Women Right to Divorce', 64; Ayah 'Abd al-Salām, 'al-Talfīq wa Tatabbu' al-Rukhas wa Tațbīqātuhu fì al-'Ibādāt wa al-Aḥwāl al-Shakhsiyyah', 67; Maszlee Malik, Talfiq: Beramal dengan Pelbagai Mazhab, 55-57.

35 al-Subkī, 'Fatawā al-Subk $\vec{\imath}$, vol. 1, 152; Maszlee Malik, 'Talfíq: Beramal dengan Pelbagai Mazhab', 56; al-Ruwayti', al-Tamadhhub, vol. 2, 1076.

36 al-Shatti, Hasan, Tajrid Zawa'id al-Ghāyah wa al-Sharh, vol. 2 (Damshiq: t.p., 2000), 175.

37 al-Ḥilwānī, al-Wasm fì al-Wasym, 55. 
satu hukum yang tidak dipersetujui oleh kedua-duanya dan bukan bermaksud bahawa amalan talfíq ini tidak dibenarkan dengan ijmā' ulama. ${ }^{38}$

Dalil keempat pula ialah larangan pengeluaran pendapat ketiga sekiranya ulama hanya berselisih pendapat kepada dua pandangan sahaja. Pendapat yang melarang pengeluaran pendapat ketiga ini dalam perbincangan ilmu usul fiqh merupakan pendapat yang räjị sekalipun para ulama usul fiqh masih berselisih pendapat. Sebagai contoh, iddah perempuan hamil yang kematian suami, para ulama fiqh berselisih pendapat kepada dua pandangan sahaja. Pandangan pertama, 'iddah perempuan yang kematian suami ini ialah sehingga melahirkan anaknya, manakala pandangan kedua ialah mana-mana tempoh yang lebih panjang di antara tempoh melahirkan anak ataupun tempoh empat bulan sepuluh hari. Rentetan daripada itu, mana-mana ulama fiqh selepas itu tidak lagi dibenarkan untuk mengeluarkan pendapat ketiga dengan mengatakan iddah perempuan yang kematian suami adalah selama tiga bulan pula. ${ }^{39}$ Berdasarkan larangan pengeluaran pendapat ketiga ini, amalan talfiq juga mempunyai persamaan dengan larangan di atas. Ini disebabkan, apabila seseorang mencampur adukkan pendapat mazhab yang pertama dan kedua, maka dia telah mengeluarkan satu pendapat baru yang tidak diiktiraf oleh mana-mana mazhab. Sekiranya seorang mujtahid pun tidak dibenarkan mengeluarkan pendapat yang ketiga, maka seorang muqallid juga lebih utama untuk dihalang daripada mengeluarkan pendapat baru yang tidak bertepatan dengan mana-mana mazhab. ${ }^{40}$

Dalil keempat ini telah dikritik dengan mengatakan qiyās yang cuba dilakukan di antara masalah talfiq dan pengeluaran pendapat ketiga adalah qiyās yang tidak tepat (قياس مع الفارق). Ini disebabkan larangan pengeluaran pendapat ketiga adalah ditujukan kepada mujtahid, sedangkan talfiq berlaku

\footnotetext{
38 al-Ruwayti', al-Tamadhhub, vol. 2, 1077.

39 al-'Anzī, Sa'ad 'al-Talfĩq fī al-Fatawā', Majallah al-Sharī'ah wa al-Dirāsat alIslāmiyyah, 38 (1999), 277; Maszlee Malik, Talfiqq: Beramal dengan Pelbagai Mazhab, 55 \& 56; al-Zuḥaylī, Wahbah, Ușūl al-Fiqh al-Islāmī, vol. 2 (Damshiq: Dār al-Fikr, 1986), 1144.

40 al-Nablusī, 'Abd al-Ghanī bin Isma'il, Khulāṣah al-Tahquīq fì Bayān Hukm alTaqlid wa al-Talfíq (Istanbul: Maktabah al-Haqīqah, 1986), 18; Pagani, Samuela, 'The Meaning of the Ikhtilāf Al-Madhāhib in 'Abd Al-Wahhab al-Sha'rani's al-Mizan al-Kubra', Islamic Law and Society, 11/2 (2004): 189; Ayah 'Abd alSalām, 'al-Talfĩq wa Tatabbu' al-Rukhas wa Taṭbīqātuhu fī al-'Ibādāt wa al-Aḥwāl al-Shakhsiyyah', 67; Nūr Shahīrah Muḥammad Nașir, 'al-Naẓr fī Ma'alat alAf'āl fĩ al-Ta'amul ma'a al-Shabakah al-'Ankabūtiyyah: Dirāsah Maqāṣidiyyah Taṭbīqiyyah’ (Master, Al al-Bayt University, 2013), 41.
} 
dalam kalangan muqallid sahaja. ${ }^{41}$ Sekiranya kita bersetuju bahawa qiyās ini tepat dan boleh digunakan, dalil ini masih boleh ditolak kerana larangan pengeluaran pendapat ketiga adalah merujuk kepada masalah yang sama, sedangkan amalan talfiq boleh berlaku dalam dua masalah yang berbeza. Kritikan ini cuba dijawab dengan mengatakan talfiq juga boleh berlaku dalam masalah yang sama seperti dalam masalah wuduk sahaja sehingga boleh menyebabkan berlaku pengeluaran pendapat ketiga.

Dalil keempat ini turut dikritik dengan mengatakan larangan pengeluaran pendapat ketiga menurut pendapat yang paling räjih ialah apabila terdapat titik persamaan di antara kedua-dua pendapat. Sekiranya tidak terdapat titik persamaan di antara kedua-duanya, pendapat yang paling rājịh dalam kalangan ulama usul fiqh masih tidak menghalang pengeluaran pendapat ketiga. Contoh bagi masalah yang mempunyai titik persamaan ialah masalah harta pusaka bagi datuk dan saudara-saudara si mati. Para ulama berselisih pendapat sama ada datuk berhak mendapat keseluruhan harta ataupun datuk perlu berkongsi harta bersama saudara-saudara si mati. Di sini terdapat titik persamaan di antara pendapat pertama dan kedua iaitu datuk mesti mendapat habuan daripada harta pusaka si mati dalam mana-mana keadaan sekalipun. Sekiranya seorang mujtahid lain selepas perselisihan ini mengeluarkan pendapat yang ketiga dengan mengatakan harta pusaka diberikan keseluruhannya kepada saudarasaudara si mati, maka pendapat ini telah menafikan titik persamaan di antara kedua-dua pendapat yang sebelumnya dan pendapat ini ditolak.

Contoh bagi masalah yang tidak mempunyai titik persamaan ialah masalah haiwan sembelihan yang tidak disebutkan nama Allah ketika penyembelihan. Para ulama berselisih pendapat kepada dua pandangan. Pandangan pertama, haiwan harus di makan dalam apa jua keadaan. Pandangan kedua pula haiwan ini tidak harus di makan dalam semua keadaan. Sekiranya seorang mujtahid mengeluarkan pendapat ketiga dengan mengatakan haiwan yang tidak disebutkan nama Allah secara sengaja ketika penyembelihan, haiwan ini tidak boleh dimakan, manakala haiwan yang tidak disebutkan nama Allah secara tidak sengaja, haiwan ini harus dimakan, maka pendapat ini diterima kerana ia tidak menafikan titik persamaan di antara kedua-dua pendapat sebelumnya. ${ }^{42}$ Berdasarkan keterangan ini, terdapat perbezaan yang nyata di antara larangan pengeluaran ketiga seperti mana yang dikehendaki oleh pendapat yang räjih , dengan konsep talfiq . Ini disebabkan, tidak terdapat titik persamaan di antara pendapat mazhab pertama dan kedua ketika mana seorang muqallid cuba menggabungkan pendapat di antara keduanya. Oleh itu, meskipun talfíq cuba

${ }_{41}$ Krawietz, Birgit, 'Cut and Paste in Legal Rules: Designing Islamic Norms with Talfĩq', Die Welt des Islams, 42/1 (2002): 10.

42 al-Ruwayti', al-Tamadhhub, vol. 2, $1059 \& 1060$. 
diqiyaskan dengan pengeluaran pendapat ketiga, ia masih lagi dihukumkan sebagai harus. ${ }^{43}$

Dalil kelima bagi golongan yang mengharamkan talfiq ialah percampuran pendapat di antara mazhab yang pertama dan kedua akan menghasilkan satu hukum yang dianggap batal oleh kedua-dua mazhab. Ini disebabkan, pendapat yang digunakan oleh orang yang mengamalkan talfiq adalah tidak menepati mana-mana pendapat mazhab sebelumnya, seolah-olahnya dia telah mencipta satu mazhab baru yang khusus untuk dirinya. ${ }^{44}$ Dalil ini telah dikritik dengan mengatakan sesuatu hukum hanya dianggap batal di sisi sesuatu mazhab apabila seseorang itu melakukan perkara-perkara yang dianggap batal oleh mazhabnya. Ini berbeza apabila seseorang itu bertaqlid kepada mazhab yang lain, maka ia tidak boleh dihukumkan batal pada ketika itu kerana dia sedang mengikut dan bertaqlid kepada pendapat mazhab yang lain. ${ }^{45}$

Kritikan lain bagi dalil kelima ini ialah dakwaan yang mengatakan hukum yang terhasil daripada percampuran kedua-dua mazhab adalah hukum yang batal di sisi kedua-dua mazhab, juga tidak boleh diterima. Ini kerana, ia bertentangan dengan kerangka asas dalam perselisihan pendapatpendapat mazhab, di mana mazhab Malikī tidak akan mengatakan pernikahan pengikut mazhab Shāfi'ī sebagai batal disebabkan ketiadaan mahar sehingga mengakibatkan pembatalan sebahagian besar pernikahan golongan Shāfi'iyyah. Manakala mazhab Shāfi ‘ī juga tidak mengatakan pernikahan pengikut mazhab Malikī sebagai batal disebabkan ketiadaan saksi sehingga membatalkan sebahagian besar pernikahan golongan Malikiyyah pula. Kritikan ini dijawab semula dengan mengatakan mazhab Malikī tidak membatalkan pernikahan mazhab Shāfi‘ ${ }^{1}$ dan begitu juga sebaliknya dengan syarat apabila seseorang itu bertaqlid salah satu daripada mazhab dan memelihara semua syarat yang ditetapkan oleh mazhab itu. Ini berbeza dengan amalan talfiq di mana seseorang itu akan bertaqlid kepada sebahagian pendapat mazhab dalam perkara tertentu dan menyalahi pendapat mazhab tersebut dalam syarat-syarat yang ditetapkan di dalamnya. ${ }^{46}$

43 al-Hifnawī, Tabsir al-Nujaba' bi-Haqūqāt al-Ijtihād wa al-Taqlid wa al-Talfìq wa al-Ifta', 272.

44 Ayah 'Abd al-Salām, 'al-Talfĩq wa Tatabbu' al-Rukhas wa Taṭbīqātuhu fĩ al'Ibādāt wa al-Aḥwāl al-Shakhsiyyah', 68; 'Udaybat, 'al-Tarakhkhus fī Masa'il alIkhtilāf fī al-Fiqh al-Islāmī: Dirāsah Ta'siliyyah Tatbiqiyyah-Masa'il Mu'āmalāt fì Qararat Majmā' al-Fiqh al-Islāmī fì Jaddah Anmudhajan', 75; al-Ruwayti’, alTamadhhub, vol. 2, 1077.

45 Ibn al-Mala Farukh, Muḥammad 'Abd al-'Azim, al-Qawl al-Sadid fì ba'd alMasa'il al-Ijtihād wa al-Taqlid (Kuwait: Dār al-Da'wah, 1988), 95 \& 96.

46 Amir Badi Shah, Muhammad Amin, Taysīr al-Taḥrīr, vol. 4 (Beirūt: Dār al-Fikr, t.t.), 372 . 
Dalil keenam bagi golongan yang mengharamkan talfiq ialah kebenaran di sisi Allah adalah satu seperti mana yang ditetapkan oleh para ulama usul fiqh. Apabila kebenaran di sisi Allah hanya satu, maka seseorang hanya boleh mengikut salah satu daripada pendapat mazhab sahaja dan tidak boleh mencampurkan pendapat kedua-duanya sekali. Ini kerana, seseorang yang bertaqlid kepada mazhab tertentu, maka dia telah berkeyakinan bahawa pendapat mazhabnya adalah pendapat yang rājih dan pendapat mazhab lain pula adalah marjūh. Dia juga berkeyakinan bahawa pendapat mazhabnya adalah pendapat yang benar, manakala pendapat mazhab yang lain adalah salah sekalipun terdapat kemungkinan kecil bahawa ia adalah benar. Oleh itu, talfiq adalah tidak dibenarkan kerana apabila seseorang melakukan talfiq, maka dia telah mencampurkan perkara yang benar dan salah dalam satu masalah. ${ }^{47}$

Perbincangan berkenaan kebenaran (الحق) di sisi Allah berada pada satu pendapat sahaja atau berada pada semua pendapat (ketika mana para ulama berselisih pendapat) merupakan permasalahan khilaf dalam kalangan ulama usul fiqh. Sebahagian ulama berpendapat bahawa kebenaran berada pada semua pendapat kerana keharusan untuk beramal dengan mana-mana pendapat ulama menunjukkan bahawa kesemua pendapat adalah benar di sisi Allah. Sebahagian yang lain pula berpendapat bahawa kebenaran di sisi Allah hanyalah satu sekalipun ia tidak dapat dipastikan. Ini kerana, mustahil sesuatu perkara itu boleh dihukumkan halal dan haram serentak pada satu-satu masa dan pada individu yang tertentu. Pendapat yang kedua ini merupakan pendapat yang rājịh dalam kalangan ulama seperti Abū Hanīfah, Mālik, al-Shāfi '`i dan para fuqaha yang lain. ${ }^{48}$

Dalil bagi golongan yang mengharamkan talfiq ini boleh dikritik dengan mengatakan sekalipun kebenaran di sisi Allah adalah satu, akan tetapi ia tidak dapat ditentukan dengan tepat. Oleh itu, terdapat kemungkinan bahawa hukum yang terhasil daripada amalan talfiq merupakan hukum yang sebenar di sisi Allah. Kritikan ini disanggah semula kerana seorang yang bertaqlid kepada salah satu mazhab perlu berkeyakinan bahawa pendapat yang dipegang dalam mazhabnya itu merupakan pendapat yang tepat di sisi Allah dan pendapat yang bertentangan dengannya adalah salah. Maka tidak harus baginya untuk mencampurkan pendapat daripada kedua-dua mazhab itu kerana ia akan menghasilkan satu hukum yang bercampur di antara perkara yang benar dan salah berdasarkan keyakinannya. ${ }^{49}$

47 al-Safarinī, al-Tahqū̃ fì Butlān al-Talfìq, 176.

48 al-Zarkashī, al-Bahr al-Muhit, vol. 6, 241-243.

49 al-Zarkashī, al-Baḥr al-Muhiț, vol. 6, 321; al-Nablusī, Khulāṣah al-Tahquīq fì Bayān Hukm al-Taqlid wa al-Talfiq, 6. 


\section{Golongan yang Mengharuskan Penggunaan Talfíq berserta Dalil yang Digunakan}

Pendapat yang mengharuskan talfiq merupakan pendapat daripada tarīqah al-mughārabah ${ }^{50}$ daripada golongan Malikiyyah. ${ }^{51}$ Pendapat ini juga turut disokong oleh Ibn Nujaym (m.1563M), Amir Badi Shah (m.1565M), Ibn Mulla Farrukh (m.1642M), Mar'ī al-Hanbalī (m.1624M), Hasan al-Shatti (m.1889M). ${ }^{52}$ Kebanyakan ulama $m u$ 'àsirīn juga berpegang kepada pendapat yang mengharuskan talfíq, antaranya al-Bani, Sa'd al-'Anzī, Wahbah Zuhaylī, al-Ruwayti', Nașīr 'Abd Allāh al-Mayman, al-Ḥifnawī dan ramai lagi. ${ }^{53}$ Sungguhpun begitu, Kebanyakan ulama yang mengharuskan talfiq tetap meletakkan beberapa syarat. Antaranya tidak melakukan tatabbu' al-rukhas, tidak merujuk semula hukum yang telah ditaqlidkan, tidak membawa sehingga ke tahap pembatalan hukuman yang dijatuhkan oleh hakim, terdapat darurat atau keperluan dalam melakukan talfiq dan tidak membawa kepada perkara yang haram secara jelas di sisi syarak.

Antara dalil yang digunakan oleh golongan ini bagi menyokong pendapat yang mengharuskan talfíq ialah firman Allah SWT di dalam surah al-Anbiyā', ayat tujuh:

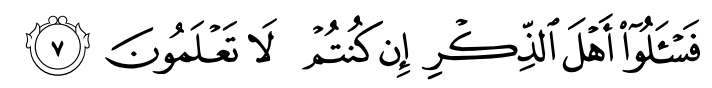

"Maka bertanyalah kamu kepada Ahl al-Zikr jika kamu tidak mengetahui..."

(Surah al-Anbiyā', 21: 7)

50 Antara tokoh-tokoh daripada tarīqah al-mughārabah dalam kalangan Malikiyyah adalah seperti Shaqran al-Qayrawani (m.802M), Ibn Farukh (m.792M), Ibn Ziyad (m.799M), Ibn Ghanim al-Ra'ini (m.788M), Asad bin al-Furat (m.828M) dan Sahnun bin Sa'id (m.854M). Sila rujuk 'Alī Jum'ah, 'al-Madkhal ila Dirāsah alMadhāhib al-Fiqhiyyah', 142 \& 143.

51 al-Dussuqi, Hāshiyah al-Dussuqi 'ala al-Sharh al-Kabīr, vol. 1, 20.

52 Muḥammad Aḥmad Siraj \& 'Alī Jum'ah, Rasa'il Ibn Nujaym (Qāhirah: Dār alSalām, 1999), 240; Amir Badi Shah, Taysīr al-Tahrī̄r, vol. 4, 254; Ibn al-Mala Farukh, 'al-Qawl al-Sadid fì Ba'd al-Masa'il al-Ijtihād wa al-Taqlid', 94; alSafarin̄̄, al-Tahquìq fì Buṭlān al-Talfìq, 160; al-Shatti, Tajrid Zawa'id al-Ghayah wa al-Sharh, vol. 2, 164-175.

53 al-Ban̄i, 'Umdah al-Tahqīq fì al-Taqlid wa al-Talfìq, 188; al-'Anzī, "al-Talfīq fī al-Fatawā," 286; al-Zuhaylī, Ușūl al-Fiqh al-Islāmī, 1148; al-Ruwayti', alTamadhhub, vol. 2, 1084; al-al-Mayman, 'al-Talfĩq fĩ al-Ijtihād wa al-Taqlid', 16; al-Hifnaw̄i, Tabsir al-Nujaba' bi-Haqīqāt al-Ijtihād wa al-Taqlid wa al-Talfìq wa al-Ifta', 272. 
Dalam ayat ini, Allah SWT mengarahkan kepada kita supaya bertanya kepada orang yang lebih mengetahui tentang perkara-perkara yang kita tidak tahu hukum-hakamnya. Allah SWT juga tidak mewajibkan kepada seseorang untuk beriltizam dengan satu pendapat atau satu individu sahaja tanpa mengambil pandangan yang lain. Justeru, dakwaan yang menghalang seseorang daripada melakukan talfiq dengan mengambil pendapat mazhab yang lain adalah bertentangan dengan ayat ini. ${ }^{54}$ Dalil ini boleh dikritik semula kerana ayat ini hanya menyuruh seseorang supaya mengambil pendapat daripada orang-orang yang berilmu dan tidak pula menyuruh supaya mencampur adukkan pendapatpendapat ahli ilmu ini. Ini kerana, pendapat yang terhasil daripada amalan talfiq ialah pendapat individu yang mencampurkan pendapat itu sendiri dan tidak boleh dinisbahkan lagi kepada pendapat para ahli ilmu. Justeru itu, amalan talfiq pada hakikatnya adalah tidak dibenarkan berdasarkan ayat di atas. Kritikan ini boleh ditolak dengan mengatakan dakwaan bahawa pendapat yang terhasil daripada amalan talfíq ini tidak boleh dinisbahkan kepada ahli ilmu adalah tidak tepat. Ini kerana pendapat-pendapat tersebut pada asalnya adalah berpunca daripada ahli ilmu tersebut dan bukan rekaan daripada individu yang mengambil dan mencampurkan adukkan pendapat-pendapat ini.

Dalil yang kedua, golongan yang mengharuskan talfiq berhujahkan kepada satu kaedah fiqh yang terkenal iaitu asal bagi segala permasalahan adalah harus selagi mana tidak terdapat dalil yang mengharamkannya. Kaedah ini bertepatan dengan konsep talfiq kerana tidak terdapat dalil yang menegah daripada penggunaan talfiq. ${ }^{55}$ Dalil ini dikritik semula dengan mengatakan terdapat banyak dalil yang menjelaskan tentang pengharaman talfiq. Maka, dakwaan yang menyatakan tidak terdapat dalil yang menegah keharusan talfiq adalah ditolak.

Dalil yang ketiga ialah Allah tidak menjadikan kesukaran dan kesusahan dalam SyariatNya. Bahkan Allah SWT telah menetapkan bahawa Syariat Islam ini merupakan Syariat yang paling mulia dan diturunkan dengan segala jenis kemudahan seperti mana yang dinyatakan di dalam banyak ayat al-Quran dan hadis Nabi SAW. Justeru itu, larangan penggunaan talfíq akan memberi memberikan kesusahan kepada umat dalam melaksanakan

54 al-Zuhaylī, al-Rukhaș al-Shar 'iyyah (Beirūt: Dār al-Khayr, 1993), 60; Maszlee Malik, Talfiq: Beramal dengan Pelbagai Mazhab, 64, 79 \& 80.

55 al-Safarinī, al-Tahqīq fì Buțlān al-Talfìq, 168; al-Ruwayti', al-Tamadhhub, vol. 2, 1080; 'Udaybat, 'al-Tarakhkhus fĩ Masa'il al-Ikhtilāf fì al-Fiqh al-Islāmī: Dirāsah Ta'siliyyah Tatbiqiyyah-Masa'il Mu'āmalāt fì Qararat Majmā' al-Fiqh al-Islāmī fì Jaddah Anmudhajan', 74; al-Mayman, 'al-Talfĩq fì al-Ijtihād wa al-Taqlid', 17; Maszlee Malik, Talfìq: Beramal dengan Pelbagai Mazhab, 63-74. 
segala tanggungjawab yang telah diamanahkan. Larangan talfiq juga akan menyebabkan seseorang hanya boleh bertaqlid kepada satu mazhab sahaja walaupun mazhab tersebut meletakkan syarat yang ketat dan rumit dalam pelaksanaan sesuatu hukum. Antara nas-nas yang menyatakan kemudahan dan kesenangan yang diberikan oleh Syariat Islam kepada umatnya ialah firman Allah SWT:

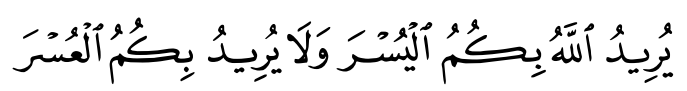

"Allah menghendaki kamu beroleh kemudahan, dan tidak menghendaki kamu menanggung kesukaran..."

(Surah al-Baqarah, 2: 85)

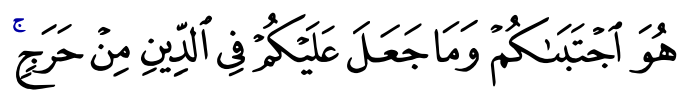

"Dan Dia tidak menjadikan kamu menanggung sesuatu keberatan dan susah payah dalam perkara Agama..."

(Surah al-Hajj, 22: 78 )

Nas-nas daripada hadis SAW pula ialah:

$$
\text { بعثت بالحنفيّة السّمحة }
$$

“Aku dibangkitkan dengan agama yang suci dan bertolak ansur..." 56

$$
\text { ما خيّر النبيّ صلى الله عليه وسلم بين الأمرين إلاّ اختار أيسر هما }
$$

"Nabi SAW tidak akan diberi pilihan di antara dua perkara melainkan baginda akan memilih yang paling mudah di antara keduanya..." 57

Selain itu, banyak juga kaedah fiqh yang menyokong dalil ini antaranya

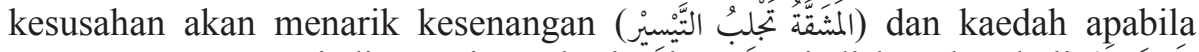
sesuatu urusan menjadi sempit, maka ia ákan menjadi luas kembali (إذَا ضَاقََّ (الأمرْ اتَََّعَ

56 Hadis riwayat al-Haythamī, Kitāb al-Nikāḥ Bāb Ḥaq al-Mar'ah 'ala al-Zawj, no. hadis 7613. Lihat al-Haythamī, al-Hafīz Nūr al-Dīn 'Alī bin Ab̄̄ Bakr, Majmā' alZawa'id wa Manba 'al-Fawa'id, vol. 4 (Beirūt: Dār al-Fikr, 1994), 555.

57 Hadis riwayat al-Bukhārī, Kitāb al-Ḥudūd, Bab Iqāmah al-Ḥudūd wa al-Intiqām li Hurmatillah, no. hadis 6786. Lihat al-Bukhārī, Abū 'Abd Allāh Muḥammad bin Ismā‘il, Saḥ̄ḥ al-Bukhārī (Damshiq: Dār Ibn Kathīr, 2002), 1680. 
Kritikan terhadap dalil ini antara lain ialah alasan untuk mengharuskan talfiq berdasarkan kepada kemudahan dan kesenangan yang diberikan oleh Syariat Islam ini akan membawa kepada pengguguran taklif secara keseluruhan. Kesemua taklifan yang ditetapkan oleh Allah kepada manusia sememangnya akan membawa kepada kesusahan dan memberatkan. Ia bersesuaian dengan perkataan taklif itu sendiri yang bermaksud bebanan dan kesusahan. Sekiranya setiap kesusahan yang terdapat pada taklif perlu diangkat, maka segala hukum taklïfi seperti bersuci, solat, zakat, haji, jihad dan lain perlu diangkat juga. Semua ini adalah mustahil, adakah disebabkan Allah SWT sangat suka kepada perkara yang mudah sehingga menyebabkan segala taklif digugurkan? Sesungguhnya, mengambil perkara yang mudah tanpa bersandarkan kepada dalil-dalil syarak adalah perbuatan menurut hawa nafsu yang sangat ditegah oleh Islam. Keluasan yang diberikan oleh Islam hanya dibenarkan dalam ruang lingkup perkara-perkara yang bertepatan dengan usul syarak sahaja. Manakala, mengikut hawa nafsu dan tidak merujuk kepada dalil dalam melaksanakan sesuatu hukum pula adalah bertentangan sama sekali dengan $u s ̦ u \bar{l} l$ syarak. ${ }^{58}$

Jawapan terhadap kritikan ini ialah Syariat Islam secara keseluruhannya adalah taklif sama ada pelaksanaannya itu sangat memberatkan mukallaf ataupun tidak. Keharusan penggunaan talfiq dapat memberi kelonggaran kepada mukallaf untuk memilih pendapat yang lebih mudah untuk dirinya ketika melaksanakan segala tanggungjawab yang ditetapkan oleh Islam. Ini lebih bertepatan dengan nas-nas daripada al-Quran dan hadis di atas. Sebaliknya memilih pendapat yang lebih susah daripada pandangan-pandangan yang terdapat dalam sesuatu mazhab adalah bersandarkan kepada ijtihad ulama semata-mata. Justeru itu, adalah lebih baik untuk kita mengutamakan nas-nas yang jelas daripada al-Quran dan hadis daripada ijtihad para ulama. Mengambil pendapat yang mudah juga tidak bermaksud seseorang itu mengikut hawa nafsu. Hadis yang tersebut di atas jelas menunjukkan bahawa Nabi SAW lebih suka untuk memilih perkara yang lebih mudah dan terdapat banyak rukhsah yang dibenarkan oleh al-Quran bagi memberikan kemudahan dan kesenangan kepada umat Islam. ${ }^{59}$

Dalil keempat ialah pengharaman talfíq akan membawa kepada mudarat yang amat besar iaitu membatalkan sebahagian besar ibadat dan amalan yang dilakukan oleh orang awam. Mereka juga boleh dihukumkan sebagai fasiq kerana melakukan ibadat yang batil, ibadat-ibadat yang telah dilakukan perlu diqad̄a' semula dan mereka berhak dikenakan azab di akhirat kelak. Perkara ini dapat kita saksikan secara jelas pada masa kini di mana amat sukar untuk

58 al-Shāțibī, al-Muwāfaqāt, vol. 5, 105.

59 Maszlee Malik, Talfiq: Beramal dengan Pelbagai Mazhab, 88 \& 89. 
kita menjumpai seorang awam yang melakukan solat atau perkara-perkara lain yang bertepatan dengan mana-mana mazhab. Bahkan, apa yang kita dapati ialah orang awam pada kebiasannya akan meninggalkan beberapa rukun dan syarat daripada mana-mana mazhab ataupun dia akan melakukan perkara yang merosakkan dari satu sudut dan melakukan perkara yang diharamkan dari sudut yang lain. Semua yang dia lakukan tersebut adalah hasil daripada percampuran beberapa pendapat mazhab yang masih menghukumkan ibadat ataupun muamalat tersebut sebagai sah. Pengharaman talfiq akan menyebabkan kebanyakan ibadat dan juga muamalat yang dilakukan oleh orang awam dianggap sebagai tidak sah dan terbatal. Ini akan menyebabkan kesusahan dan kesempitan yang amat sangat kepada umat Islam yang kebanyakannya dikategorikan sebagai orang awam. ${ }^{60}$

Dalil seterusnya ialah tidak terdapat naqal daripada sahabat atau tabiin, sekalipun mereka banyak berselisih pendapat dan mempunyai sifat kewarakan yang tinggi, bahawa mereka pernah berkata kepada orang ramai yang meminta fatwa daripada mereka:

\section{"kamu semua diwajibkan untuk memelihara segala hukum yang terdapat di dalam mazhab supaya kamu terpelihara daripada melakukan talfiq..."}

Akan tetapi, mereka hanya mengeluarkan fatwa kepada orang ramai tanpa memperincikan keperluan untuk memelihara segala hukum mazhab. Sekiranya talfiq merupakan sesuatu yang tidak dibenarkan, maka sudah pasti mereka tidak akan mengabaikan penerangan berkenaan hukum talfiq ini. ${ }^{61}$

Dalil ini boleh dikritik dengan mengatakan sekalipun tidak terdapat naqal berkenaan larangan para sahabat dan tabiin daripada melakukan talfíq dan mengambil mana-mana pendapat daripada ulama yang diakui keilmuannya, akan tetapi terdapat satu perbincangan dalam ilmu usul fiqh yang menghalang amalan ini. Perbincangan tersebut ialah apabila berlaku perselisihan di antara para ulama, mustaftī perlu memilih salah satu pendapat dan bukan mencampur adukkan di antara pendapat-pendapat tersebut. ${ }^{62}$ Perbincangan ini menunjukkan sekalipun tidak terdapat larangan yang jelas daripada kalangan sahabat, tabiin dan para imam mujtahid yang lain berkenaan pengamalan talfiq, keperluan untuk memilih satu pendapat atau satu mazhab sahaja sememangnya telah

60 al-Shatti, Tajrid Zawā'id al-Ghāyah wa al-Sharh, vol. 2, 167; al-Safarin̄̄, alTahquìq fì Buṭlān al-Talfìq, 160.

61 al-Safarinī, al-Taḥqīq fì Buṭlān al-Talfìq, 167; al-'Anzī, 'al-Talfīq fì al-Fatawā', 276 \& 278; Maszlee Malik, Talfiq: Beramal dengan Pelbagai Mazhab, 69, 82-85.

62 al-Ghazzalī, Abū Ḥamid Muḥammad bin Muḥammad, al-Mustașfā, vol. 4, 145; al-‘Anzī, 'al-Talfĩq fì al-Fatawā', 153 \& 154. 
diketahui dalam kalangan mereka kerana tidak dinafikan bahawa para sahabat, tabiin dan para imam mujtahid sangat arif dalam bidang usul fiqh sekalipun ilmu tersebut masih belum ditulis dengan lengkap pada zaman tersebut.

Dalil keenam ialah salah satu perbincangan di dalam ilmu usul fiqh berkenaan keperluan untuk beriltizam dengan satu mazhab sahaja ataupun tidak. Pendapat yang rājiḩ di dalam masalah ini ialah tidak wajib bagi muqallid untuk bertaqlid dengan satu mazhab. Bahkan, harus baginya bertaqlid dengan salah satu mazhab dalam masalah tertentu kemudian bertaqlid dengan mazhab yang lain dalam masalah yang lain pula. ${ }^{63}$ Amalan talfiq juga berpunca daripada taqlid dan ia juga sebenarnya merupakan faedah daripada taqlid. Justeru itu, apabila amalan taqlid di antara beberapa mazhab adalah dibenarkan mengikut pendapat yang räjih̆, maka amalan talfiq di antara mazhab juga adalah wajar untuk dibenarkan. ${ }^{64}$ Dalil ini boleh dikritik semula dengan mengatakan meskipun pendapat yang räjị tidak mewajibkan untuk iltizam dengan satu mazhab sahaja, tetapi para ulama juga menetapkan syarat bahawa taqlid kepada mazhab yang lain hanya dibenarkan sekiranya ia tidak membawa kepada talfiq. ${ }^{65}$

Kritikan ini telah dijawab semula dengan menolak keperluan perletakan syarat yang tidak membenarkan amalan talfiq ketika seseorang ingin bertaqlid kepada pandangan mazhab yang lain. Ini kerana, syarat ini secara tidak langsung telah menafikan faedah taqlid kepada mana-mana mazhab yang dibenarkan oleh para ulama tanpa perlu beriltizam kepada salah satu daripadanya. Kebenaran untuk bertaqlid kepada mana-mana mazhab sepatutnya memberikan kebebasan kepada seorang muqallid kerana taqlid merupakan satu-satunya pilihan yang ada bagi seseorang muqallid dalam melaksanakan segala tuntutan agama. Sebaliknya, larangan daripada melakukan talfiq telah menyempitkan ruang untuk bertaqlid. Ia juga bakal menimbulkan kerisauan kepada muqallid berhubung status kesahihan sesuatu amalan yang dilakukan sekalipun dia mengambil sesuatu pandangan tersebut daripada para ulama yang muktabar. ${ }^{66}$

Dalil ketujuh bagi keharusan penggunaan talfiq ialah satu kaedah fiqh yang menyatakan "Orang awam tidak ditetapkan mazhab bagi mereka,

\footnotetext{
63 al-Nablusī, Khulāṣah al-Tahquĩq fì Bayān Hukm al-Taqlid wa al-Talfìq, 8.

64 al-Safarinī, al-Tahqīq fì Buṭlān al-Talfìq, 160-163; al-'Anzī, 'al-Talfìq fì alFatawā', $278 \& 279$.

65 al-'Atibī, 'al-Talfīq bayn al-Madhāhib al-Fiqhiyyah wa 'Alaqatuhu bi Taysīr alFatwa', 31; al-Safarinī, al-Taḥqì fì Buṭlān al-Talfìq, 175; al-Malibarī, Fath alMu 'in, vol. 4, 249 \& 250; al-Subkī, Fatawā al-Subki, vol. 1, 152.

66 al-Shatti, Tajrid Zawa'id al-Ghayah wa al-Sharh, vol. 2, 167.
} 


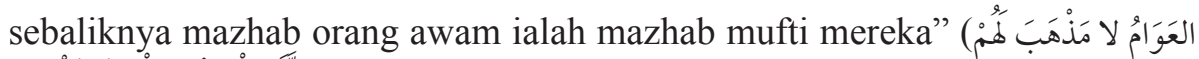
الحَ kérana orang awam tidak dikhususkan mazhab tertentu ketika melakukan sesuatu amalan. Bahkan mazhab mereka hanyalah keperluan untuk menepati salah satu pendapat imam mujtahid bagi sesuatu masalah dan menepati pendapat salah seorang imam mujtahid lagi dalam masalah yang lain pula. Ini merupakan hakikat pengamalan talfiq. ${ }^{67}$ Dalil ini dikritik semula oleh golongan yang mengharamkan talfiq kerana mereka berpendapat kaedah ini sebenarnya menyokong larangan penggunaan talfiq. Ini disebabkan nas kaedah ini sendiri yang menyatakan mazhab orang awam ialah mazhab mufti mereka. Persoalannya, mufti mazhab manakah yang akan mengeluarkan fatwa yang bertentangan dengan mazhab mereka sendiri dan membenarkan sesuatu ibadat atau muamalat yang terhasil daripada percampuran pendapat beberapa mazhab? Jikalau muqallid itu sendiri yang menghukumkan bahawa sesuatu ibadat atau muamalat itu sebagai sah, maka dia telah membuat satu mazhab yang baru bagi dirinya seperti para imam mujtahid yang lain dan ia sememangnya merupakan satu perkara yang batil. ${ }^{68}$

Dalil yang kelapan ialah para imam mujtahid sendiri melakukan talfiq dengan mengambil pendapat orang lain sekalipun ia bertentangan dengan pandangan yang dipegangnya. Sebagai contoh, Imam Ahmad bin Hanbal berpendapat bahawa perbuatan berbekam adalah membatalkan wuduk. Walau bagaimanapun beliau telah ditanya tentang hukum bersolat di belakang imam yang baru selesai berbekam, adakah sah solat makmum di belakangnya? Beliau lantas menjawab "Apakah tidak sah untuk aku bersolat di belakang Imam Malik dan Sa'id bin al-Musayyib? Contoh yang lain pula ialah Imam Abū Hanīfah turut berpendapat bahawa berbekam membatalkan wuduk. Imam Malik pula pernah mengeluarkan fatwa kepada Khalifah Harun al-Rashid bahawa berbekam tidak membatalkan wuduk. Lalu khalifah pernah pada suatu hari mendirikan solat selepas berbekam dan Abū Yūsuf, anak murid kepada Imam Abū Hanīfah telah menjadi makmum di belakangnya dan Abū Yusuf tidakpun mengulangi semula solat tersebut.

Contoh seterusnya ialah kisah Abū Yūsuf pernah mandi di salah sebuah kolam. Selepas solat jumaat, beliau diberitahu bahawa terdapat bangkai tikus dalam kolam tersebut. Maka beliau tidak mengulangi semula dengan solat zuhur dan beliau berkata "kita berpegang kepada pendapat saudara-saudara kita di Madinah (pendapat mazhab Imam Malik), apabila air telah sampai dua

\footnotetext{
al-Shatti, Tajrid Zawā'id al-Ghāyah wa al-Sharh, vol. 2, 167.

68 al-Nablusī, Khulāṣah al-Tahqūq fì Bayān Hukm al-Taqlid wa al-Talfìq, 28; Maszlee Malik, Talfiq: Beramal dengan Pelbagai Mazhab, 56.
} 
kolah, maka ia tidak lagi menanggung najis”. Imam Shāfi ‘ì juga pernah solat subuh di masjid yang berhampiran dengan makam Imam Abū Hanīfah. Lalu beliau telah meninggalkan bacaan doa qunut kerana menghormati pandangan Imam Abū Hanīfah. ${ }^{69}$

Contoh-contoh yang dikemukakan di atas telah dikritik oleh golongan yang mengharamkan talfiq. Ini kerana, semua contoh di atas telah dilakukan oleh imam-imam yang sampai tahap mujtahid. Kesemua mereka ini dibenarkan untuk berijtihad dan mereka juga tidak dibenarkan untuk mengikut pendapat mujtahid lain. Oleh itu, fatwa yang dikeluarkan oleh Aḥmad bin Hanbal, Abū Yūsuf dan al-Shāfi'i seperti contoh di atas adalah hasil daripada ijtihad mereka dan bukan kerana mereka mengikut pendapat mujtahid lain semata-mata. Fatwa ini juga kemungkinan dikeluarkan pada ketika itu sahaja, lalu mereka telah merujuk dan menarik semula fatwa tersebut dan digantikan dengan fatwa lain yang kekal sehingga kini. Justeru itu, dalil ini ditolak kerana amalan para mujtahid seperti dalam contoh-contoh di atas tidak boleh dinamakan sebagai talfiq. Selain itu, keharusan yang diberikan kepada mujtahid untuk mengeluarkan fatwa daripada pendapat mujtahid yang lain tidak boleh diberikan kepada muqallid kerana mereka tidak mempunyai kemampuan untuk berijtihad pada dalil dan mengistinbatkan sesuatu hukum daripadanya. ${ }^{70}$

\section{Pendapat yang Dipilih}

Merujuk kepada dalil-dalil yang digunakan oleh golongan yang mengharamkan talfiq, kebanyakan dalil yang digunakan adalah kaedah-kaedah yang terdapat dalam ilmu usul fiqh yang masih diperselisihkan dalam kalangan ulama. Kaedah seperti hukum pengeluaran pendapat ketiga dan kebenaran di sisi Allah satu atau berbilang-bilang adalah kaedah-kaedah yang menjadi perdebatan dalam kalangan para ulama usul fiqh. Justeru itu, menjadikan kaedah-kaedah ini sebagai dalil bagi pengharaman talfiq akan menyebabkan hukum pengharaman talfíq juga menjadi agak lemah. Ini kerana pengkritik boleh mengatakan bahawa mereka lebih cenderung kepada pendapat yang mengharuskan pengeluaran pendapat ketiga dan pendapat yang mengatakan kebenaran di sisi Allah adalah berbilang-bilang. Lebih-lebih lagi, apabila kita merujuk kepada dalil-dalil yang digunakan oleh kedua-dua belah pihak yang berselisih pendapat pada kaedah-kaedah ini, kita akan dapati bahawa perselisihan pendapat tersebut merupakan perselisihan yang kuat.

69 al-'Anzīi, 'al-Talfĩq fī al-Fatawā', 276 \& 277; Maszlee Malik, Talfìq: Beramal dengan Pelbagai Mazhab, 80-82.

70 al-Nablusī, Khulāṣah al-Tahquìq fì Bayān Hukm al-Taqlid wa al-Talfìq, 25 \& 26. 
Dalil lain yang digunakan oleh golongan ini ialah penggunaan konsep talfiq akan membawa kepada perkara-perkara yang haram seperti menghalalkan zina dan arak serta menyebabkan pelbagai kerosakan dalam Syariat Islam. Dalil ini boleh merujuk kepada salah satu kaedah dalam ilmu usul fiqh iaitu menutup pintu-pintu yang boleh membawa kepada kerosakan (سد الذرائع). Walau bagaimanapun, kaedah ini masih merupakan kaedah atau dalil yang diperselisihkan dalam kalangan ulama. Dalil ini juga tidak boleh digunakan sewenang-wenangnya kerana para ulama yang mengiktiraf kaedah ini sebagai salah satu sumber hukum syarak turut meletakkan syarat-syarat tertentu dalam penggunaannya. ${ }^{71}$ Selain itu, dakwaan bahawa talfiq boleh membawa kepada penghalalan hukum zina dan arak adalah ditolak sama sekali kerana golongan yang mengharuskan talfiq turut tidak membenarkan penggunaan talfiq sehingga membawa kepada pembatalan hukum yang telah disepakati oleh sekalian ulama. Dalil ini juga boleh dianggap sebagai terkeluar daripada tempat perselisihan para ulama (خارج عن محل النزاع).

Bagi golongan yang mengharuskan talfiq pula, mereka banyak menggunakan dalil-dalil yang umum bagi menunjukkan keharusan penggunaan talfiq. Ayatayat al-Quran dan hadis-hadis yang menunjukkan kemudahan yang diberikan oleh Syariat Islam telah digunakan bagi mewajarkan penggunaan talfiq. Mereka juga berhujah dengan ayat al-Quran yang menyuruh supaya bertanya kepada ahli ilmu tanpa mensyaratkan keperluan untuk mengikuti segala rukun dan syarat yang ditetapkan oleh ahli ilmu tersebut. Sifat umum yang terdapat pada dalil-dalil ini menyebabkan ia terdedah kepada penafsiran yang berbeza daripada golongan yang tidak bersetuju dengan penggunaan talfiq. Mereka boleh beranggapan bahawa pengharaman talfiq masih tetap memberikan kesenangan dan kemudahan dalam Syariat. Golongan yang melarang talfiq juga berpendapat bahawa larangan talfiq tidak bertentangan dengan suruhan supaya mengambil pandangan ahli ilmu berkenaan hukum hakam agama sekalipun mereka mengehadkan pengambilan tersebut daripada seorang ahli ilmu sahaja dalam satu-satu permasalahan termasuk segala rukun dan syarat yang ditetapkan oleh ahli ilmu tersebut.

Golongan yang mengharuskan talfiq juga berhujahkan kepada beberapa kaedah seperti 'asal sesuatu perkara adalah harus', 'orang awam tidak ditetapkan mazhab baginya' dan satu permasalahan dalam ilmu usul fiqh iaitu 'hukum beriltizam dengan mazhab tertentu' bagi meyokong dakwaan mereka. Mereka telah menafsirkan kaedah-kaedah dan permasalahan di atas bagi menunjukkan keharusan penggunaan konsep talfiq. Walau bagaimanapun, golongan yang mengharamkan talfiq tidak menafikan kebenaran kaedahkaedah dan permasalahan tersebut. Cuma, mereka berpandangan bahawa

$\overline{71}$ al-Zuhaylī, Wahbah, Ușūl al-Fiqh al-Islāmī, vol. 2, 884-889. 
kaedah-kaedah dan permasalahan ini pada hakikatnya lebih sesuai untuk dijadikan dalil bagi golongan yang mengharamkan talfiq seperti mana yang telah dijelaskan oleh penyelidik di dalam perbincangan dalil yang kedua, keenam dan ketujuh bagi golongan yang mengharuskan talfiq. Justeru itu, ia kembali kepada penggunaan dalil-dalil yang terlalu umum sehingga menyebabkan amat mudah bagi pengkritik untuk menolak dalil-dalil yang digunakan oleh golongan yang mengharuskan talfiq ini.

Secara keseluruhannya, penyelidik masih berpandangan bahawa keduadua belah pihak telah mengemukakan dalil-dalil yang agak kuat sekalipun masih terdapat ruang untuk kritikan terhadap dalil-dalil tersebut. Justeru itu, adalah sukar bagi penyelidik untuk memilih salah satu pendapat dengan hanya berdasarkan kepada dalil-dalil di atas kerana ciri-ciri pendapat yang lebih kuat adalah pendapat yang dapat menjawab segala kritikan yang dikemukakan terhadapnya dengan sempurna. Sungguhpun begitu, berdasarkan keterangan di atas, penyelidik cenderung untuk mengambil jalan pertengahan dan berhatihati (ihtiyāt) dalam memilih pendapat yang lebih tepat dan kuat dari sudut dalil-dalil yang digunakan. Penggunaan konsep ihtiyāt merupakan salah satu kaedah tarjīh seperti mana yang dinyatakan oleh al-Amidī di dalam kitab al-

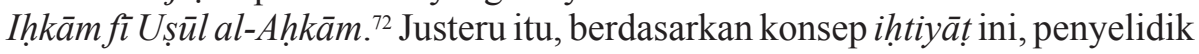
berpandangan bahawa pendapat yang mengharamkan talfiq adalah lebih wajar untuk diutamakan dalam keadaan yang normal atau biasa atas beberapa faktor.

Antaranya, kaedah-kaedah usul fiqh yang digunakan merupakan kaedahkaedah yang rājịh dalam kalangan ulama usul fiqh sekalipun ia termasuk dalam kaedah-kaedah yang masih diperselisihkan dalam kalangan ulama. Manakala kaedah-kaedah yang digunakan oleh golongan yang mengharuskan talfiq tidak dinafikan kesahihannya oleh golongan yang mengharamkan talfiq. Sebaliknya, mereka mengiktiraf kaedah-kaedah tersebut serta mendakwa kaedah-kaedah ini sebenarnya lebih sesuai untuk digunakan sebagai dalil bagi pengharaman talfiq . Faktor yang lain pula ialah kelonggaran yang diberikan dalam penggunaan talfiq akan memberi ruang kepada orang awam untuk bersifat terlalu mengambil mudah dalam melaksanakan segala hukum yang diperintahkan oleh Islam. Mereka akan sentiasa mengambil peluang untuk memilih pendapat yang lebih mudah dengan alasan bahawa pendapat tersebut turut disokong oleh para ulama yang diperakui keilmuannya dalam bidang ilmu Islam. Ia juga boleh menyebabkan orang awam tidak lagi berusaha untuk mendalami ilmu tentang hukum-hakam yang terdapat di dalam sesebuah mazhab sedangkan tradisi inilah yang menghasilkan para ilmuan

al-Amidī, 'Alī bin Muḥammad, al-Iḥkām fì Ușūl al-Aḥkām, vol. 4 (Riyāḍ: Dār alSumay'i), 327. 
Islam sama ada mereka yang mampu mencapai tahap yang tinggi sehingga mampu berijtihad ataupun sekurang-kurangnya menghasilkan individu yang mempunyai kefahaman yang tepat dan bersedia untuk menyampaikan setiap hukum yang telah disyariatkan kepada masyarakat.

Perlu ditegaskan di sini juga, pilihan penyelidik untuk mengutamakan pendapat yang mengharamkan talfiq hanya dikhususkan kepada golongan muqallid dan tidak ditujukan kepada golongan mujtahid sama ada mujtahid tersebut merupakan mujtahid mutlak atau mujtahid mutajazzi'. Ini kerana, para mujtahid tidak mengeluarkan hukum berdasarkan pendapat-pendapat yang dikeluarkan oleh mana-mana mazhab sehingga boleh menyebabkan berlaku amalan talfiq. Mereka hanya mengeluarkan hukum berdasarkan dalil-dalil yang diiktiraf kesahihannya oleh syarak, sekalipun hukum yang dikeluarkan tersebut memberi gambaran bahawa ia merupakan gabungan hukum daripada beberapa mazhab. ${ }^{73}$ Sungguhpun begitu, para mujtahid perlu memastikan bahawa ijtihad yang dilakukan itu tidak melanggar ijm $\bar{a}$ ' para ulama dan tidak menyebabkan berlaku pengeluaran pendapat ketiga (dan seterusnya) dengan syarat terdapat titik persamaan dalam permasalahan khilafiyyah yang telah berlaku dalam kalangan para ulama sebelum ini. Sekiranya tidak wujud titik persamaan tersebut, maka pengeluaran pendapat ketiga adalah dibenarkan kepada para mujtahid.

Bagi golongan muqallid pula, mereka perlu berusaha untuk mengelak daripada berlaku amalan talfiq dengan mengikuti segala hukum yang ditetapkan di dalam sesebuah mazhab. Sekiranya terdapat kesempitan dan kesusahan dalam mengamalkan hukum-hukum yang ditetapkan di dalam sesebuah mazhab yang dipegang oleh seorang muqallid, sedangkan mazhab yang lain pula dapat memberikan lebih banyak kelonggaran kepada dirinya, maka dia diberi pilihan untuk menggunakan pendapat daripada mazhab yang lain dengan mengikuti segala rukun dan syarat yang ditetapkan oleh mazhab yang lain tersebut. Ini merujuk kepada pendapat yang membenarkan perpindahan mazhab yang mana ia dipersetujui oleh golongan yang mengharuskan talfiq dan sebahagian besar golongan yang mengharamkan talfiq. Sekiranya tidak terdapat pilihan yang terbaik selain daripada penggunaan talfiq, maka penggunaan talfiq menurut penyelidik boleh dibenarkan dalam ruang lingkup yang diperlukan sahaja khususnya dalam permasalahan-permasalahan yang membabitkan keperluan masyarakat umum seperti permasalahan haji, permasalahan kewangan dan muamalat Islam, pengkodifikasian undang-undang jenayah Islam dan lain-lain. Ini disebabkan, ketegasan dalam menegah amalan talfiq tidak sewajarnya mengakibatkan kesulitan yang bersangatan terhadap umat Islam

73 al-'Atibi, 'al-Talfīq bayn al-Madhāhib al-Fiqhiyyah wa 'Alaqātuhu bi Taysīr alFatwa', 32. 
dalam melaksanakan segala hukum yang telah ditetapkan. Ini dikuatkan lagi dengan fakta bahawa hukum berkenaan talfiq masih dikategorikan sebagai permasalahan khiläfiyyah di mana pendapat yang mengharuskan talfíq juga mempunyai dalil-dalil tersendiri bagi menyokong pendapat tersebut.

Justeru itu, ketika mana penggunaan talfiq amat diperlukan bagi memberi kemaslahatan kepada masyarakat, ia hendaklah dilakukan oleh individu yang mempunyai kemahiran dan kefahaman tentang sesuatu permasalahan yang memerlukan kepada konsep talfiq dan tidak boleh sewenang-wenangnya dilakukan oleh sebarang individu yang tidak mempunyai kelayakan dalam bidang ini. ${ }^{74}$ Ini bagi mengelakkan perbuatan mencari sesuatu yang mudah sahaja dalam Syariat Islam sehingga menyebabkan hilang sifat bebanan (تكليف) dalam pensyariatan sesuatu hukum. Ia juga bagi memastikan hikmah pensyariatan sesuatu hukum itu (مقاصد الشريعة) terpelihara meskipun setelah berlakunya amalan talfiq tersebut. Selain itu, para ulama juga boleh menggunakan talfiq sekiranya merasakan bahawa hukum-hukum yang terdapat di dalam sesebuah mazhab terlalu sempit bagi memberikan penyelesaian terhadap permasalahanpermasalahan semasa. Konklusinya, darurat yang benar-benar mendesak atau hajat yang bersangatan merupakan satu justifikasi yang amat kuat untuk mengharuskan penggunaan talfiq sebagai contoh dalam proses penggubalan undang-undang, permasalahan ekonomi, politik dan lain-lain.

\section{KESIMPULAN}

Sebagai kesimpulan, penyelidik berpandangan bahawa konsep talfiq merupakan salah satu kaedah penyelesaian hukum yang masih wajar digunakan khususnya dalam penyelesaian hukum bersifat semasa. Sekalipun perbincangan berkenaan hukum penggunaan konsep talfiq telah dibincangkan oleh ramai penulis sebelum ini, akan tetapi, artikel ini menghimpunkan sebanyak mungkin dalil-dalil yang dikemukakan oleh para ulama terdahulu mahupun kontemporari berkenaan permasalahan talfiq. Kebanyakan dalil-dalil ini juga, khususnya dalil-dalil bagi golongan yang menentang penggunaan konsep talfiq, telah disebut secara berasingan dalam penulisan-penulisan yang berbeza sehingga menyukarkan analisis yang lebih tepat diberikan terhadap perbezaan pandangan yang wujud dalam permasalahan ini. Artikel ini juga telah membincangkan dan mengkritik dalil-dalil tersebut bagi memastikan kesesuaian penggunaannya sebagai sandaran hujah kepada pihak-pihak yang berselisih pendapat berkenaan hukum penggunaan konsep talfiq dalam penyelesaian hukum-hukum syarak.

74 Ghazala Ghalib Khan, 'Application of Talfìq in Modern Islamic Commercial Contracts', Policy Perspectives, 10/2 (2013): 133. 
Seterusnya, penyelidik telah membuat kesimpulan bahawa penggunaan konsep talfiq perlu berada dalam peringkat terakhir iaitu apabila penyelesaian hukum dalam sesebuah mazhab tidak dapat memberikan penyelesaian terbaik bagi mengangkat kesulitan dan kemudaratan yang sedang dihadapi oleh masyarakat. Pada peringkat awal, penggunaan pandangan mazhab yang menjadi rujukan utama sesebuah negara perlu diutamakan dengan mematuhi segala rukun dan syarat yang ditetapkan oleh sesebuah mazhab tersebut. Ini perlu dilakukan bagi memelihara kedudukan mazhab yang sentiasa dipandang tinggi khususnya kedudukan mazhab Shāfi'ī yang telah menjadi sumber rujukan utama dalam penyelesaian hukum syarak di negara ini bagi satu tempoh yang sangat panjang. Penggunaan pandangan mazhab Shāfi‘ī juga merupakan lambang kepada penyatuan dan perpaduan sesebuah masyarakat. Ia bertujuan untuk mengelakkan berlakunya perselisihan pendapat dalam permasalahan yang tidak sepatutnya membawa kepada perpecahan kepada masyarakat di negara ini.

Pada peringkat pertengahan pula, para ulama boleh memberikan kebenaran kepada masyarakat untuk menggunakan pandangan mazhab selain daripada mazhab Shāfi‘̄i dengan syarat mereka mematuhi sepenuhnya segala rukun dan syarat yang ditetapkan dalam mazhab tersebut. Perpindahan mazhab ini hanya dilakukan dalam permasalahan tertentu dengan tujuan untuk memberi kemudahan dan mengangkat kesulitan daripada masyarakat. Perpindahan ini juga dilakukan secara keseluruhan bermaksud para ulama perlu memastikan masyarakat mematuhi sepenuhnya segala ketetapan yang dibuat di dalam mazhab yang lain tersebut. Pada peringkat terakhir, sekiranya para ulama berpendapat bahawa perpindahan kepada pandangan mazhab lain secara keseluruhan akan menyebabkan kemudaratan yang dihadapi oleh masyarakat masih tidak mampu dihilangkan, maka penggunaan konsep talfiq boleh dijadikan pilihan bagi menyelesaikan permasalahan masyarakat tersebut. Penggunaan konsep talfiq hendaklah dilakukan pada tahap darurat atau tahap hajat yang menepati kedudukan darurat. Ini menunjukkan bahawa penggunaan talfiq hanya dilakukan dalam keadaaan yang sangat terdesak, lantas mengecualikannya daripada hukum pengharaman penggunaan talfiq dalam keadaan biasa dan normal. Para ulama boleh mentarjīhkan manamana pandangan mazhab berdasarkan dalil-dalil yang menjadi sandaran kepada pandangan mazhab-mazhab tersebut dengan tujuan untuk memberikan penyelesaian terbaik kepada masyarakat pada ketika ini. Justeru itu, para ulama perlu memerhatikan peringkat-peringkat seperti mana yang dinyatakan di atas sebelum mengaplikasikan konsep talfiq dalam penyelesaian hukum yang bersifat semasa. 


\section{RUJUKAN}

'Abd al-'Aziz Aḥmad al-'Usfur, Fatwā 'Ulamā' al-Ahsa' wa Masā'iluhum (Beirūt: Dār al-Basha’ir al-Islāmiyyah, 2001).

'Ala' al-Dīn 'Alī bin Husam al-Dīn al-Burhān Furī, Kanz al- 'Ummal (Beirūt: Mu'assasah al-Risālah, 1985).

'Alī Jum'ah, al-Madkhal iIa Dirāsah al-Madhāhib al-Fiqhiyyah (Qāhirah: Dār al-Salām, 2009).

al-'Anzī, Sa'ad, 'al-Talfīq fī al-Fatawā', Majallah al-Sharī'ah wa al-Dirāsah al-Islāmiyyah, 38 (1999), 269-308.

al-'Atib̄̄, Ghazī bin Murshid, 'al-Talfīq bayn al-Madhāhib al-Fiqhiyyah wa 'Alaqātuhu bi Taysīr al-Fatwa', (Seminar Garis Panduan Fatwa anjuran al-Majmā' al-Fiqh al-Islamī di Mekah, Arab Saudi, pada 17-20 Januari 2009).

'Udaybat, 'al-Tarakhkhus fī Masa'il al-Ikhtilāf fī al-Fiqh al-Islāmī: Dirāsah Ta’siliyyah Tatbiqiyyah-Masa'il Mu'āmalāt fī Qararat Majmā‘ al-Fiqh al-Islāmī fì Jaddah Anmudhajan', (Ph.D Thesis, The World Islamic Sciences and Education University, Amman, Jordan, 2012).

Abū Bakr Muhammad Shata al-Dumyatī al-Bakrī, I'ānah al-Ṭālibìn, vol. 4 (Qāhirah: Dār Iḥyā’ al-Kutub al-'Arabiyyah, t.t.)

al-Amidī, 'Alī bin Muḥammad, al-Iḥkām fì Uṣūl al-Aḥkām (Riyāḍ: Dār alSumay'i).

Amir Badi Shah, Muhammad Amin, Taysīr al-Taḥrīr (Beirūt: Dār al-Fikr, t.t).

Ayah 'Abd al-Salām, 'al-Talfīq wa Tatabbu' al-Rukhas wa Taṭbīqātuhu fī al'Ibādāt wa al-Aḥwāl al-Shakhsiyyah', (Master in Islamic Judiciary, College of Graduate Studies, Hebron University, Hebron, Palestin, 2006).

Badran, Abū al-'Inin, Ușūl al-Fiqh (Iskandariah: Mu'assasah Shabab alJami'ah., t.t.).

al-Banī, Muhammad Sa'id, 'Umdah al-Tahqīq fì al-Taqlid wa al-Talfíq (Damshiq: Dār al-Qadiri, 1997)

al-Bukhārī, Abū 'Abd Allāh Muḥammad bin Ismā'il al-Bukhārī, Saḥịh alBukhārī (Damshiq: Dār Ibn Kathīr, 2002).

Dussuqi, Shams al-Dīn Muḥammad 'Arafah, Hāshiyah al-Dussuqi 'ala alSharh al-Kabīr (Qāhirah: Dār Ihyā̄' al-Kutub al-'Arabiyyah, t.t.).

Fareeha Khan, 'Traditionalist Approaches to Shariah Reform: Mawlana Ashraf Ali Thanawi Fatwa on Women Right to Divorce', (Ph.D, The University of Michigan, United States of America, 2008). 
al-Fayruz al-Abadi, Muḥammad bin Ya'qūb, al-Qamūs al-Muhiṭ (Beirūt: Dār Ihyā' al-Turāth al- 'Arab̄̄, 2000).

Gesink, Indira Falk, 'Islamic Reformation: A History of Madrasa Reform and Legal Change in Egypt', Comparative Education Review, 50.3 (2006): 325-345.

Ghazala Ghalib Khan, 'Application of Talfiq in Modern Islamic Commercial Contracts', Policy Perspectives, 10.2 (2013): 141-166.

al-Ghazalī, Abū Hamid Muḥammad bin Muhammad, al-Mustașfā (Madinah: Al-Jami'ah al-Islāmiyyah-Kuliyyah al-Shari'ah, t.t.).

al-Haythamī, al-Hafĩz Nūr al-Dīn 'Alī bin Abī Bakr, Majmā' al-Zawa'id wa Manba' al-Fawa id (Beirūt: Dār al-Fikr, 1994).

al-Hifnawī, Muhammad Ibrāhim, Tabsīr al-Nujaba' bi-Haqūqāt al-Ijtihād wa al-Taqlid wa al-Talfìq wa al-Ifta' (Qāhirah: Dār al-Hadīth, 1995).

al-Ḥilwān̄̄, Aḥmad bin Aḥmad, al-Wasm fì al-Wasym (Qāhirah: Matba'ah alMaymaniyyah, 1905).

Ibn al-'Uqayl, Abū al-Wafa' 'Alī bin 'Uqayl, al-Wadih fì Ușūl al-Fiqh, vol. 5 (Beirūt: Mu’assasah al-Risālah, 1999).

Ibn al-Mala Farukh, Muhammad 'Abd al-'Azim, al-Qawl al-Sadid fì ba'd alMasa 'il al-Ijtihād wa al-Taqlid (Kuwait: Dār al-Da'wah, 1988).

Ibn Manẓūr, Muḥammad bin Mukram, Lisān Al- 'Arab (Beirūt: Dār al-Ṣadr, t.t.).

Krawietz, Birgit, 'Cut and Paste in Legal Rules: Designing Islamic Norms with Talfiq', Die Welt des Islams, 42.1 (2002), 3-40.

al-Malibari, Zayn al-Dīn bin 'Abd al-'Azīz, Fath al-Mu 'in (Beirūt: Dār alFikr, 2002).

Maszlee Malik, Talfiq: Beramal dengan Pelbagai Mazhab (Shah Alam: Karya Bestari Sdn. Bhd., 2005).

al-Mayman, Nasir 'Abd Allāh, 'al-Talfīq fī al-Ijtihād wa al-Taqlid', dalam alNawāzil al-Tasyri ‘yyah (Al-Dammam: Dār Ibn al-Jawzi, 2008), 5-30.

Muḥammad Aḥmad Siraj \& 'Alī Jum'ah, Rasa'il Ibn Nujaym (Qāhirah: Dār al-Salām, 1999).

al-Nablusī, 'Abd al-Ghanī bin Isma'il, Khulāṣah al-Taḥqīq fì Bayān Hukm alTaqlid wa al-Talfì (Istanbul: Maktabah al-Haqīqah, 1986).

Nūr Shahīrah Muhammad Nașir, ‘al-Naẓr fī Ma'alat al-Af'āl fì al-Ta'amul ma ‘a al-Shabakah al-'Ankabūtiyyah: Dirāsah Maqāṣidiyyah Taṭbīqiyyah’ (Master, Al al-Bayt University, 2013). 
Pagani, Samuela, "The Meaning of the Ikhtilāf al-Madhāhib in "Abd alWahhab al-Sha"rani's al-Mizan al-Kubra', Islamic Law and Society, 11.2 (2004), 177-212

Ruwayti’, Khalid bin Musa'id, al-Tamadhhub, vol. 2 (Riyāḍ: Dār alTadmuriyyah, 2013).

al-Safarin̄ī, Muḥammad bin Aḥmad, al-Taḥqīq fì Buṭlān al-Talfìq (Riyāḍ: Dār al-Sumay'i, 1998)

Saqqaf, 'Alawi Muḥammad, al-Fawa'id al-Makkiyyah (Beirūt: Dār al-Kutub al-'Ilmiyyah, 2008).

al-Subkī, Taqī al-Dīn 'Alī bin 'Abd al-Kafi, Fatawā al-Subki (Beirūt: Dār alKutub al-'Ilmiyyah, 2004).

al-Shațib̄i, Abū Isḥāq Ibrāhim bin Mūṣā, al-Muwāfaqāt, vol. 5 (al-Khubar: Dār Ibn al-'Affan, 1997).

al-Shatti, Hasan, Tajrid Zawa 'id al-Ghāyah wa al-Sharh (Damshiq: t.p., 2000).

Zaman, Saminaz, 'Amrikan Shari'a: The Reconstruction of Islamic Family Law in the United States', South Asia Research, 28.2 (2008), 185-20.

al-Zarkashī, Badr al-Dīn Muhammad bin Bahadur, al-Baḥr al-Muhit, vol. 6 (Hurghada: Dār al-Ṣafwah, 1992)

Zuhaylī, Wahbah, al-Rukhaṣ al-Shar 'iyyah (Beirūt: Dār al-Khayr, 1993).

Zuhaylī, Wahbah, Ușūl al-Fiqh al-Islāmī, vol. 2 (Damshiq: Dār al-Fikr, 1986).

\section{Temu bual}

Hassan Ahmad, Datuk Seri (Ahli Majlis Penasihat Syariah Bank Negara Malaysia; Mantan Mufti Kerajaan Negeri Pulau Pinang 1997-2014), dalam temu bual beliau bersama penyelidik, pada 18 Ogos 2015. 
Jurnal Syariah, Jil. 25, Bil. 3 (2017) 363-394 